\title{
Effects of spinal immobilization devices on pulmonary function in healthy volunteer individuals
}

\author{
Sağlıklı gönüllü kişilerde spinal immobilizasyon cihazlarının \\ pulmoner fonksiyonlara etkisi
}

\author{
Didem AY, ${ }^{1}$ Can AKTAŞ, ${ }^{1}$ Sabiha YEŞILYURT, ${ }^{2}$ Sezgin SARIKAYA, ${ }^{2}$ \\ Aslı ÇETİN, ${ }^{1}$ Emine Sevda ÖZDOĞAN ${ }^{2}$
}

\section{BACKGROUND}

We aimed to investigate the effects of spinal immobilization devices on pulmonary functions.

\section{METHODS}

This study was a cross-over trial in healthy volunteer subjects; 60 volunteers were included. We performed a full spirometry in the supine position, and forced vital capacity (FVC), forced expiratory volume in one second (FEV1) and FEV1/FVC were recorded in all subjects. Then, Philadelphia type cervical collar (Philly) and Kendrick extrication device (KED) were applied to all subjects. We measured FVC, FEV1, FEV1/FVC in all subjects in the supine position at the 5th and 30th minutes after application of cervical collar and KED. After a one-hour relaxation period, Philly and long spinal backboard with straps were applied to all subjects. FVC, FEV1, FEV1/FVC were measured again in all subjects at the 5th and 30th minutes after application of cervical collar and long spinal backboard.

\section{RESULTS}

After application of KED, baseline levels were compared with levels at the 5th and 30th minutes. Statistically significant decreases were determined in FEV1 $(p=0.000)$ and FVC levels $(p=0.000)$ after application of KED, but there were no significant differences in FEV1/FVC levels. After application of the long spinal backboard, a comparison of baseline levels and levels at the 5th and 30th minutes demonstrated statistically significant decreases in FEV1 $(p=0.000)$ and FVC levels $(p=0.000)$, but no significant difference in FEV1/FVC levels.

\section{CONCLUSION}

We determined that both KED and long spinal backboard cause a decrease in pulmonary functions.

Key Words: Backboard; Kendrick extrication device; pulmonary function; spinal immobilization.

\section{$\boldsymbol{A M A C}$}

Spinal immobilizasyon cihazlarının solunum fonksiyonları üzerindeki etkileri araştırıldı.

\section{GEREÇ VE YÖNTEM}

$\mathrm{Bu}$ çalışma, sağlıklı gönüllü kişilerde yapılan kesitsel bir çalışmadır, 60 gönüllü dahil edildi. Yatar pozisyondayken tam spirometre uygulandı ve tüm deneklerde zorlu vital kapasite (FVC), zorlu birinci saniye ekspiratuvar hacim (FEV1) ve FEV1/FVC kaydedildi. Sonra, Philadelphia tipi boyunluk (Philly) ve travma yeleği (Kendrick extrication device $=$ KED) tüm deneklere uyguland1. Boyunluk ve KED uygulamasından sonra 5. ve 30. dakikada tüm deneklerde FVC, FEV1 ve FEV1/FVC ölçüldü. Bir saat dinlenme zamanından sonra, tüm deneklere Philly ve uzun omurga tahtası tekrar uygulandı. Boyunluk ve uzun omurga tahtası uygulandiktan sonra tüm deneklerde 5. ve 30. dakikada FVC, FEV1 ve FEV1/FVC ölçüldü.

\section{BULGULAR}

Bazal değerler KED uygulandıktan sonra ölçülen 5. ve 30. dakika değerleri ile karşılaştırıldı. KED uygulandıktan sonra FEV1 $(p=0,000)$ ve FVC değerlerinde $(p=0,000)$ önemli derecede istatiksel anlamlı düşme bulundu, ama FEV1/ FVC değerlerinde belirgin değişiklik yoktu. Uzun omurga tahtası uygulandıktan sonra 5. ve 30. dakikada ölçülen değerleri bazal değerlerle karşılaştırıldı. Uzun omurga tahtas1 uygulandıktan sonra FEV1 $(p=0,000)$ ve FVC değerlerinde $(p=0,000)$ önemli derecede istatiksel anlamlı düşme bulundu, fakat FEV1/FVC değerlerinde belirgin değişiklik yoktu.

\section{SONUÇ}

KED ve uzun omurga tahtasının solunum fonksiyonlarını azalttığını belirledik.

Anahtar Sözcükler: Travma tahtası; travma yeleği; akciğer fonksiyonu; omurga sabitleme. 
Trauma is the leading cause of death in the young and productive population worldwide. ${ }^{[1]}$ The World Health Organization estimates that the mortality rate due to motor vehicle crashes will increase by $67 \%$ by the year 2020, and most of this increase will occur in the Middle East, North Africa and Asia. Road traffic crashes kill 1.2 million people annually worldwidean average of 3.242 people every day. ${ }^{[2]}$ Road traffic crashes injure or disable 20 to 50 million people each year. $^{[3]}$

Injury is the fourth leading cause of all deaths, but among children and adults under age 45 , it is the leading cause of death. Injury is costly to the nation in terms of productive life years lost due to premature death and long-term disability and in terms of medical resources used for the care, treatment and rehabilitation of injured persons; it is also costly to the injured persons, their families and friends due to the resultant pain and suffering it causes. ${ }^{[4]}$

Vertebral column injuries account for $4.8 \%$ of injuries; half of them are related to the cervical vertebrae. Motor vehicle crashes are the principal cause of traumatic injury to the spinal cord. Other etiologies, in descending order of frequency, include falls, gunshot wounds and injuries occurring during sports or recreational activities. ${ }^{[5]}$

Pre-hospital spinal immobilization criteria have changed largely since the development of emergency medical systems. The American Academy of Orthopedic Surgeons Committee first emphasized the signs and symptoms indicating potential spinal injuries. ${ }^{[6,7]}$

Spinal trauma should be evaluated simultaneously with airway control and maintenance at the scene of an accident. Many types of equipment have been designed to stabilize the spinal column. The Emergency Medical Service (EMS) spine immobilization intervention involves immobilizing the head, trunk and extremities of the injured patient by means of cervical collar and restraining devices attached to a long, rigid board. ${ }^{[8]}$

The Kendrick extrication device (KED) resembles a life jacket and is used for extrication of the victim from the vehicle; it helps in immobilizing the spinal column. Its use in combination with a rigid cervical collar provides complete immobilization of the head and torso. These systems are often used to immobilize patients with suspected spinal cord injury (SCI) during extrication after a motor vehicle crash. Application of these devices may be time-consuming, and therefore, they should only be applied if there are no life-threatening injuries and the patient's vital functions are stable. ${ }^{[9]}$

Our aim in this study was to demonstrate whether or not KED and long spinal backboard restrict pulmo- nary functions. Both the Zee Extrication Device (ZED) and KED encircle the body while providing spinal immobilization and can limit pulmonary functions.

\section{MATERIALS AND METHODS}

We designed a cross-over trial among healthy volunteer subjects. After planning, we obtained permission from the ethical committee. Sixty volunteers were included (33 female, 55\%; 27 male, 45\%). Their median age was $27.066 \pm 6.51(\min 19-\max 53)$.

Subjects suffering from any chronic diseases, upper or lower respiratory tract infection symptoms or who were under any medication and those who failed to perform respiratory function tests were excluded from the study. Before participation, a brief physical examination was performed to confirm that none of the subjects had any abnormal findings. All subjects were informed about the study and signed the informed consent.

With Zan Ferraris $100+310$ Spirometry (Germany), we performed a full spirometry in the supine position, and forced vital capacity (FVC), forced expiratory volume in one second (FEV1) and FEV1/FVC were recorded in all subjects. Spirometric tests were performed while subjects were in the supine position since the long spinal backboard can only be applied in that position.

Spirometry is a physiological test that measures how an individual inhales or exhales volumes of air as a function of time. The patient is asked to make a deep (maximum) inspiration after a few normal breaths and then to exhale totally with a maximum effort and maximum rate. Lung volumes and flow rates are calculated. Two types of graphics are usually obtained: one shows the volume expired in seconds (Fig. 1a), while the other shows flow rates and volume changes both in expiration and inspiration (Fig. 1b).

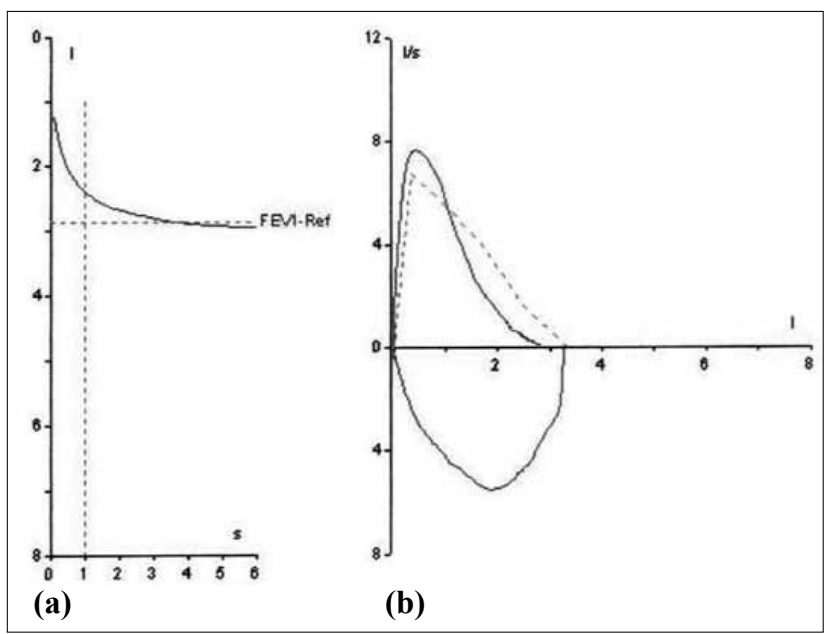

Fig. 1. (a) The volume expired in seconds. (b) Flow rates and volume changes both in expiration and inspiration. 
Table 1. Assessment of the change in pulmonary function parameters by immobilization with respect to baseline

\begin{tabular}{|c|c|c|c|c|}
\hline & \multirow[t]{2}{*}{ Mean } & \multicolumn{2}{|c|}{ Confidence interval $(95 \%)$} & \multirow[t]{2}{*}{$\mathrm{p}$} \\
\hline & & Lower & Upper & \\
\hline BASAL.FEV1 - KED5.FEV1 & ,28083 & ,22258 & ,33908 &, 000 \\
\hline BASAL.FEV1/FVC - KED5.FEV1/FVC & ,68333 & 08267 & 1,28399 &, 026 \\
\hline BASAL.FVC - KED5.FVC & ,33700 & ,27127 & ,40273 &, 000 \\
\hline BASAL.FEV1 - KED30.FEV1 & ,34217 & ,27540 & ,40893 &, 000 \\
\hline BASAL.FEV1/FVC - KED30.FEV1/FVC & ,13333 &,- 58084 &, 84750 &, 710 \\
\hline BASAL.FVC - KED30.FVC & ,41800 & ,34025 & ,49575 &, 000 \\
\hline BASAL.FEV1 - LSB5.FEV1 & ,20400 & ,14882 & ,25918 &, 000 \\
\hline BASAL.FEV1/FVC - LSB5.FEV1/FVC & ,23333 &,- 34989 & ,81656 &, 427 \\
\hline BASAL.FVC - LSB5.FVC & ,25633 & ,18368 & ,32898 &, 000 \\
\hline BASAL.FEV1 - LSB30.FEV1 &, 25717 & ,18990 & ,32443 &, 000 \\
\hline BASAL.FEV1/FVC - LSB30.FEV1/FVC &, 06667 &,- 64972 &, 78305 &, 853 \\
\hline BASAL.FVC - LSB30.FVC & ,34600 & ,25454 & ,43746 &, 000 \\
\hline KED5.FEV1 - KED30.FEV1 & ,06133 & ,00502 &, 11765 & ,033 \\
\hline KED5.FEV1/FVC - KED30.FEV1/FVC &,- 55000 & $-1,09939$ &,- 00061 &, 050 \\
\hline KED5.FVC - KED30.FVC & ,08100 &, 02402 & ,13798 & ,006 \\
\hline LSB5.FEV1 - LSB30.FEV1 &, 05317 &,- 00396 &, 11030 &, 048 \\
\hline LSB5.FEV1/FVC - LSB30.FEV1/FVC &,- 16667 &,- 78892 & ,45559 &, 594 \\
\hline LSB5.FVC - LSB30.FVC & ,08967 &, 03355 & , 14579 & ,002 \\
\hline KED5.FEV1 - LSB5.FEV1 &,- 07683 &,- 14181 &,- 01186 &, 021 \\
\hline KED5.FEV1/FVC - LSB5.FEV1/FVC &,- 45000 & $-1,00756$ & ,10756 &, 112 \\
\hline KED5.FVC - LSB5.FVC &,- 08067 &,- 15412 &,- 00721 & ,032 \\
\hline KED30.FEV1 - LSB30.FEV1 &,- 08500 &,- 14513 &,- 02487 & ,006 \\
\hline KED30.FVC - LSB30.FVC &,- 07200 &,- 13517 &,- 00883 & ,026 \\
\hline KED30.FEV1/FVC - LSB30.FEV1/FVC &,- 06667 &,- 63516 &, 50183 &, 815 \\
\hline
\end{tabular}

KED: Kendrick's extrication device. LSB: Long spinal backboard.

Vital capacity (VC) is the maximal volume of air exhaled from a position of full inspiration. FVC is the maximal volume of air exhaled with maximally forced effort from a maximal inspiration. FEV1 is the maximal volume of air exhaled in the first second of forced expiration from a position of full inspiration.

Philadelphia type cervical collar (Philly) and KED were applied to all subjects, according to the instructions of National Association of EMS Physicians and guidelines of Pre-Hospital Trauma Life Support. FVC, FEV1 and FEV1/FVC were measured in all subjects in the supine position at the 5th and 30th minutes after application of the cervical collar and KED.

After a one-hour relaxation period, Philadelphia type cervical collar (Philly) and long spinal backboard with straps were applied to all subjects, according to the instructions of the National Association of EMS Physicians and guidelines of Pre-Hospital Trauma Life Support. FVC, FEV1 and FEV1/FVC were measured in all subjects at the 5th and 30th minutes after application of the cervical collar and long spinal backboard.

For all measures, three separate tests were performed for each parameter and the best scores were used for data analysis. The SPSS 16 statistical program was used for all data analysis. Pulmonary function tests were compared by Student's t test.

\section{RESULTS}

We first compared baseline and 5th minute levels after application of KED. We found statistically significant decreases in FEV1 $(p=0.000)$ and FVC $(p=0.000)$ levels, but there were no significant differences in FEV1/FVC levels ( $\mathrm{p}>0.05)$ (Table 1).

We then compared baseline and 30th minute levels after application of KED. The decreases in FEV1 and FVC levels were statistically significant $(p=0.000)$, but there were no significant differences between basal and 30th minute FEV1/FVC levels ( $\mathrm{p}>0.05)$ (Table 1).

Baseline and 5th minute levels were then compared after application of the long backboard. Statistically significant decreases were determined in FEV1 $(p=0.000)$ and FVC $(p=0.000)$ levels, but there were no statistically significant differences in basal and 30th minute FEV1/FVC levels ( $p>0.05$ ) (Table 1).

When baseline and 30th minute levels were compared after application of long backboard, 30th min- 
ute FEV1 was considerably less $(p=0.000)$. There were no significant differences between basal and 30th minute FEV1/FVC levels ( $p>0.05)$. 30th minute FVC levels were also significantly decreased $(\mathrm{p}=0.000)$ (Table 1).

A comparison of levels at the 5th and 30th minutes after application of KED was also performed. The decrease in FEV1 levels at the 30th minute was considerable $(\mathrm{p}=0.033)$. There were no significant differences between 5 th and 30th minute FEV1/FVC levels ( $p>0.05)$. FVC levels at the 5th minute were significantly higher than FVC levels at the 30th minute $(\mathrm{p}=0.006)($ Table 1$)$.

Similarly, we compared 5th and 30th minute levels after application of the long spinal backboard. We found a considerable decrease at the 30th minute in FEV1 levels $(p=0.048)$. There were no significant differences between 5 th and 30th minute FEV1/FVC levels $(\mathrm{p}>0.05)$. FVC levels at the 5th minute were significantly higher than FVC levels at the 30th minute $(\mathrm{p}=0.002)($ Table 1$)$.

A comparison of 5th minute levels after KED to 5th minute levels after long spinal backboard applications revealed significantly lower FEV1 levels after KED $(p=0.021)$. FEV1/FVC levels were not statistically different between the two groups $(p>0.05)$. Significantly lower FVC levels after KED were also demonstrated $(\mathrm{p}=0.032)($ Table 1$)$.

When 30th minute levels after KED were compared to 30th minute levels after long spinal backboard, significantly lower FEV1 levels were determined after KED ( $p=0.006)$. FEV1/FVC levels were not statistically different between the two groups $(\mathrm{p}>0.05)$. FVC levels were also notably decreased after KED $(\mathrm{p}=0.026)($ Table 1$)$.

\section{DISCUSSION}

Currently, spinal immobilization is one of the most frequently performed procedures in the pre-hospital care of acute trauma patients worldwide. ${ }^{[10]}$ The purpose of immobilization in suspected spinal trauma is to maintain a neutral position and avoid displacement and secondary neurological injury. ${ }^{[11]}$

Recently, the use of spinal immobilization for all trauma patients, particularly those with a low likelihood of traumatic cervical SCI, has been questioned. Several materials are available for pre-hospital spinal immobilization, but none of them has yet to be defined as optimum by careful comparative analysis. Nevertheless, spinal immobilization is recommended in the resuscitation guidelines. ${ }^{[12]}$

Adequate pre-hospital care of the severely traumatized patients is important to prevent, or attenuate, early or late life-threatening complications, such as tissue hypoxia, ischemia/reperfusion injury and finally multiple organ failure. A mismatch of oxygen supply and oxygen demand is a hallmark in the pathophysiology of multiple trauma. ${ }^{[13]}$

An experimental study on healthy subjects supine on the spinal board with standard torso straps demonstrated a significant reduction in FVC and FEV1. ${ }^{[14]}$ In a study of Totten, ${ }^{[15]}$ whole body immobilization either with a backboard or vacuum mattress and collar significantly restricted ventilation when compared with no immobilization. The effects were similar under the two immobilization conditions, although the FEV1 was lower on the vacuum mattress. Respiratory restriction was more pronounced at the extremes of age. Schafermeyer et al. ${ }^{[16]}$ demonstrated that spinal immobilization limits functional vital capacity.

In our study, we also determined that the use of both KED and spinal backboard on healthy volunteers significantly decreased FEV1 and FVC, in line with the literature. In our study, both KED and long spinal backboard FEV1 and FVC decreases were even greater with extended immobilization time. A fall in functional residual capacity (FRC) can cause impaired oxygenation. This may be of particular significance in patients with chest trauma or those with diminished cardiorespiratory reserve.

Possible problems associated with SCI are acute respiratory failure and hypoxia caused by hypoventilation, aspiration or impaired diaphragmatic function as a consequence of injuries. ${ }^{[17]}$ When the SCI spares the diaphragm but paralyzes the intercostal and abdominal muscles, inadequate coughing, paradoxical rib movement on spontaneous ventilation, decrease in VC $(50 \%)$ and FRC ( $85 \%$ of predicted values), and loss of active expiration may occur. ${ }^{[18]}$ As per this study performed on the volunteers, in injuries involving FEV causing acute respiration failure and injuries involving spinal cord and low FRC, these immobilization devices should be used carefully and patients should be monitored closely, since KED and long spinal backboard may cause a fall in FRC and therefore the occurrence of impaired oxygenation.

In restrictive pathologies due to neuromuscular disease, thorax deformities or interstitial lung diseases, lung volumes are decreased but flow rates are normal, meaning that FVC is decreased and FEV1 is decreased proportionally to FVC, so the FEV1/FVC ratio remains normal.

In obstructive pathologies like asthma or chronic obstructive pulmonary disease (COPD), where there is a diffuse bronchospasm, FEV1 is decreased but FVC remains normal (only the time of total expiration increases); thus, FEV1/FVC is also decreased.

Consequences of our study indicated that both 
KED and the long spinal backboard restrict pulmonary functions. The effect is the lowering of the $\mathrm{VC}$ with no change in flow rates. In both KED and long spinal backboard groups, FEV1 and FVC decreases were greater with extended immobilization time. Thus, respiratory restriction becomes more prominent when the immobilization period is extended. Significant decreases in FEV1 and FVC were detected after KED application when compared to the long spinal backboard group, showing that restriction effects of KED on respiratory functions are more prominent.

Limitations of this study arise from the fact that it is a study in the laboratory, not in a true clinical setting, which thus includes both smoking and non-smoking patients. Since KED and long spinal backboard are applied in the supine position, basal pulmonary functions were also obtained in the supine position in the study. However, we compared measures as liters, not in percentages, and we compared basal measures to measures following KED and long spinal backboard applications in the same subjects.

In conclusion, in this study performed among volunteers, we determined that both KED and long spinal backboard cause a decrease in pulmonary functions. The decrease in the pulmonary functions becomes more pronounced when the immobilization period is extended. Thus, in SCI patients with impaired respiration and thorax traumas and in patients with low cardiac reserves suffering from multiple traumas, patients should be closely monitored in terms of oxygenation when such devices are used. Further studies are needed on actual cases, but health personnel applying spinal immobilization must consider that it can be a potential source of respiratory compromise in traumatized patients.

\section{REFERENCES}

1. Taviloğlu K, Ertekin C. Current status and future options for trauma and emergency surgery in Turkey. Ulus Travma Acil Cerrahi Derg 2008;14:10-3.

2. Peden M, Scurfield R, Sleet D, Mohan D, Hyder AA, Mathers EJ, et al. World Report on Road Traffic Injury Prevention. Geneva: World Health Organization; 2004.
3. National Center for Injury Prevention and Control. CDC Injury Fact Book. Atlanta (GA): Centers for Disease Control and Prevention; 2006.

4. Dorothy P. Rice, Ellen J. MacKenzie, and Associates. Cost of Injury in the United States: A Report to Congress. San Francisco, CA: Institute for Health \& Aging, University of California and Injury Prevention Center, The Johns Hopkins University, 1989.

5. Baron BJ, Scalea TM. Spinal cord injuries. In: Tintinalli JE, Kelen GD, Stapzynski JS, editors. Emergency medicine: a comprehensive study guide. 6th ed. New York: McGraw Hill; 2004. p. 1569-82.

6. American Academy of Orthopedic Surgeons Committee on Injuries, Fractures and dislocations of the spine. Emergency Care and Transportation of the Sick and Injured. Chicago, IL: American Academy of Orthopedic Surgeons; 1971. p. 111-5.

7. Domeier RM. Indications for prehospital spinal immobilization. National Association of EMS Physicians Standards and Clinical Practice Committee. Prehosp Emerg Care 1999;3:251-3.

8. Kwan I, Bunn F, Roberts I. Spinal immobilisation for trauma patients. Cochrane Database Syst Rev 2001;2:CD002803.

9. Bernhard M, Helm M, Aul A, Gries A. Preclinic management of multiple trauma, Anaesthesist 2004;53:887-904

10. The Section on Disorders of the spine and peripheral nerves of the american association of neurologic surgeons and the congress of neurologic surgeons. Prehospital cervical spinal immobilization following trauma. September, 2001.

11. Vickery D. The use of the spinal board after the pre-hospital phase of trauma management. Emerg Med J 2001;18:51-4.

12. American College of Surgeons. Advanced Trauma Life Support Program for doctors. 6th ed. Chicago: American College of Surgeons; 1997.

13.Ziegenfuss T. Emergency management of polytrauma patients. Zentralbl Chir 1996;121:924-42. [Abstract]

14. Bauer D, Kowalski R. Effect of spinal immobilization devices on pulmonary function in the healthy, nonsmoking man. Ann Emerg Med 1988;17:915-8.

15. Totten VY, Sugarman DB. Respiratory effects of spinal immobilization. Prehosp Emerg Care 1999;3:347-52.

16. Schafermeyer RW, Ribbeck BM, Gaskins J, Thomason S, Harlan M, Attkisson A. Respiratory effects of spinal immobilization in children. Ann Emerg Med 1991;20:1017-9.

17. Velmahos GC, Toutouzas K, Chan L, Tillou A, Rhee P, Murray $\mathrm{J}$, et al. Intubation after cervical spinal cord injury: to be done selectively or routinely? Am Surg 2003;69:891-4.

18. Mansel JK, Norman JR. Respiratory complications and management of spinal cord injuries. Chest 1990;97:1446-52. 